\title{
Hidden nutrient leaks in agricultural soils: the case of grain residues and losses
}

\author{
Portocarrero, Rocio ${ }^{1}$; Biaggi, Cristina ${ }^{1}$; Valeiro, Alejandro ${ }^{2}$ \\ ${ }^{1}$ Instituto Nacional de Tecnología Agropecuaria (INTA). Famaillá Experimental Station (Argentina) \\ 2 Instituto Nacional de Tecnología Agropecuaria (INTA). Labintex-Europe/Agropolis International (France). \\ valeiro.alejandro@inta.gob.ar
}

\begin{abstract}
More accurate nutrient balances are a key tool for keeping soils healthy and land use sustainable. In Argentina, though, they evolved towards a "black box" simplified concept with two main components: input of nutrients through mineral fertilization and output via grain harvest. However, this simplification underestimates nutrients' extraction through grazing, biomass harvesting, residues, and losses during grains' storage and transport. The study proposes an extended nutrient balance equation, and estimates the proportion of N, P, K and $\mathrm{S}$ extracted from soils in these unaccounted factors for 12 grain crops in the period 2009-2019. Compared with previous studies, estimated extraction rates are at least $46 \%$ higher for $\mathrm{N} ; 25 \%$ for $\mathrm{P}$ and $176 \%$ for $\mathrm{K}$ for the five main crops. Grain production figures showed to be good indicators of extracted nutrients in oilseeds but not in cereals, mainly due to an increased proportion destined for cattle in feed-lots. The amounts of potentially recyclable nutrients contained in secondary storage losses and residues represent $8 \%$ of the total $\mathrm{N}$ and $43 \%$ of the total $\mathrm{K}_{2} \mathrm{O}$ applied per year for all crops in Argentina. A circular economy approach to grain cleaning and storage operations could show ways to recover and recycle these residues and losses, and constitute a promising strategy for developing more resilient and productive soils.
\end{abstract}

\section{Introduction}

There is consensus about the need for a paradigm shift in soil management and food production to address the global challenges of mitigation and adaptation to climate change, the fight against soil degradation and desertification, and to achieve food safety (Tully \& McAskill, 2020; Scherer et al, 2020; Smith et al. ,2019). The bio-based circular economy continues to offer almost untapped potential for farmers and their organizations. Several United Nations Sustainable Development Goals (Zero Hunger; Health and Well-being; Clean Water and Sanitation; Responsible Consumption and Production; Climate Action; Life and Terrestrial Ecosystems) could not be achieved without healthy soils and sustainable land use.

Among the practices that could contribute to these objectives Smith et al (2019) identify - among others - the optimization of nutrient management. Nutrient balances provide information on environmental pressure: a deficit (negative value) shows a depletion in soil fertility, while a nutrient surplus (positive data) indicates a risk of soil, water or air contamination. Agroecosystems with negative nutrient balances tend to generalize from low-input agriculture in the Sahel to the relatively well-endowed soils of East Africa and Latin America (Sterk et al, 2020; D'Odorico et al., 2013;Bindraban et al, 2000).

Argentina is one of the main food producing and exporting countries in the global arena. There is much bibliography addressing nutrient balances in Argentinian agricultural soils and in the Pampa's region (macro and meso-levels), calculating the differences between the elements that leave the soils through harvests and those that are incorporated in different ways. In general terms, these studies conclude that the nutrient balances of Argentine soils are deficient, and that it is necessary to compensate the outputs applying mineral fertilizers (Cruzate \& Casas, 2009, 2012, 2017; Viglizzo et al. 2001, 2010; Lavado \& Taboada, 2009). Other studies show increasing soils' degradation due to the expansion of the agricultural frontier (Abbona et al., 2017; Flores \& Sarandón, 2003; Astarloa and Pengue, 2018). 
In order to obtain practical conclusions, macro-balances in Argentina evolved towards a "black box" simplified concept with only two components: the input of nutrients via synthetic fertilization and the output via grain harvest. However, soil nutrient balance is far more complex (Figure 1). One of the losses that is not considered is the flow of nutrients through the soil (e.g. levels of leaching, gaseous emissions, surface erosion, biological nitrogen fixation, etc.), given the complexity of its measurement. On the other hand, the production statistics of the crops are used for the outputs calculation (expressed in tons of grains), implicitly considering that they represent the only component of soil biomass export. However, the relationship between the area planted with cereals and that effectively harvested (Table 1) shows that, eventhough certain percentages are lost for different reasons, some crops are planted mainly for livestock feed (feed barley, oats, or rye) although grains are also harvested; others have mixed destinations (maize and sorghum), while there are clearly grain-harvesting ones (malting barley, bread wheat or rice).

Finally, in the calculation of the macro-balances it is usually omitted that throughout the value-chain certain percentages of biomass, representing output soil nutrients, are separated as residues (e.g. damaged kernels or foreign material), and losses during the grains' storage and transport that are not reflected either in the final production figures.

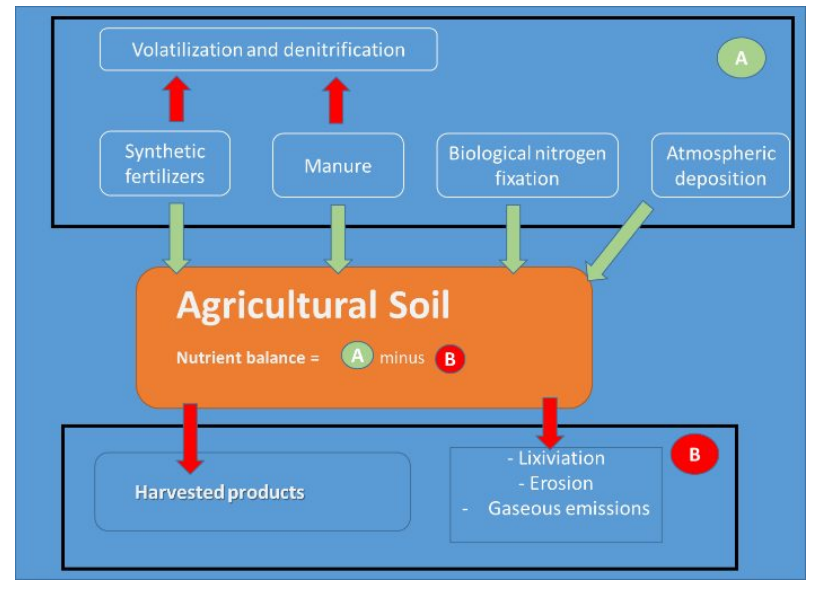

Figure 1: Main components in the calculation of soil nutrients' balance. Source: adaptation on OECD (2008)

Table 1. Average harvest/planting ratio 2009/2019

\begin{tabular}{|ll|}
\hline Crop & Ratio \% \\
\hline Corn & $78 \%$ \\
Malting barley & $92 \%$ \\
Feed barley & $15 \%$ \\
Oats & $21 \%$ \\
Sorghum & $75 \%$ \\
Rye & $14 \%$ \\
Bread wheat & $94 \%$ \\
Rice & $98 \%$ \\
Source: MAGyP; Estimaciones agrícolas 2009/2019
\end{tabular}

Our working hypothesis is that both the volumes of biomass lost along the value chain, and the residues it contained, have not been included in the final production estimates. In the same way, in desk studies, when these estimates are used to calculate national or regional balances of nutrients in soils, other biomass outputs through grazing, forage harvesting, etc. have not been considered either. 
In other words, these large-scale studies could have been underestimating the extraction of nutrients -contained in this unaccounted biomass- from these soils.

This study aims to improve the approach to the export of nutrients from Argentinian soils; provide a preliminary identification and quantification of those contained in residues and losses in major crops, and estimate their potential locations within their value-chains, where biomass recovery can have potentially positive consequences for production and soil fertility. It is seen as a crucial step in providing robust overall guidance to support stakeholders in designing more efficient crop loss or residue management systems. This is of particular interest for the promotion of more sustainable production practices, as residues and losses can constitute a technically useful resource to recover nutrients and carbon in the soils originating them, within the framework of an increasingly circular agriculture.

\section{Methodology and data used:}

The performance of agricultural biomass production in the main extensive crops in Argentina, during the 20092019 decade was analyzed with a simplified mass-balance approach. The consideration of this period captures the impacts of the most recent technological changes on the export of nutrients from Argentine agricultural soils.

A database was built including the Ministry of Agriculture, Livestock and Fisheries' information on areas planted, harvested, and their production and yields. Volumes of stubble and forages produced, and losses in grain storage and transport were estimated for each of the value chains, based on local bibliographic references.

The focus was on estimating the outflows of nitrogen $(\mathrm{N})$, phosphorus $(\mathrm{P})$, potassium $(\mathrm{K})$, and sulfur $(\mathrm{S})$, the most relevant nutrients for Argentine agricultural production.

From the conventional nutrient balance equation (Roy et al.; 2003):

$\mathbf{R n t n}=\sum \mathbf{t o n}(\mathbf{A P t}+\mathbf{A R} \Delta \mathbf{t}-\mathbf{R M} \Delta \mathbf{t}+\mathbf{L} \Delta \mathbf{t})$, (Eq 1) where:

Rntn $=$ Nutrients remaining in the soil at the end of the period considered (ton)

$\mathrm{APt}=$ Nutrients present at the beginning of the period (ton)

$\mathrm{AR} \Delta \mathrm{t}=$ Nutrients added or returned to the soil in the $\Delta \mathrm{t}$ interval (ton)

$\mathrm{RM} \Delta \mathrm{t}=$ Nutrients extracted by crops and residues in the $\Delta \mathrm{t}$ interval (ton)

$\mathrm{L} \Delta \mathrm{t}=$ Nutrients lost in the $\Delta \mathrm{t}$ interval (ton)

This study developed the RM $\Delta$ t factor -which represents the main nutrient output- as follows :

$\mathbf{R M} \Delta \mathbf{t}=\mathbf{M H p}+\mathbf{S H p}+\mathbf{H 2 R}+\mathbf{B E R}$ + L2Sto+ L2Tra, (Eq 2) where:

$\mathrm{MHp}=$ Nutrients extracted by the main harvested product (ton)

SHp $=$ Nutrients extracted by the harvested by-product or secondary product (ton)

$\mathrm{H} 2 \mathrm{R}=$ Nutrients extracted by harvest secondary residues (ton)

BER1 $=$ Nutrients extracted in the biomass of primary residues (ton)

L2Sto $=$ Nutrients extracted in secondary storage losses (ton)

L2Tra $=$ Nutrients extracted in secondary transport losses of the main product (ton)

Data was compiled from official and private estimates of grain production [MHp] of corn, sunflower, soybean, oats, rice, rye, barley (malting and feed), sorghum, peanuts and wheat (bread and pasta) from all over the 
country. These crops (Figure 2) represented in 2018/2019 more than 90\% of the total planted area in Argentina (INDEC; 2019).

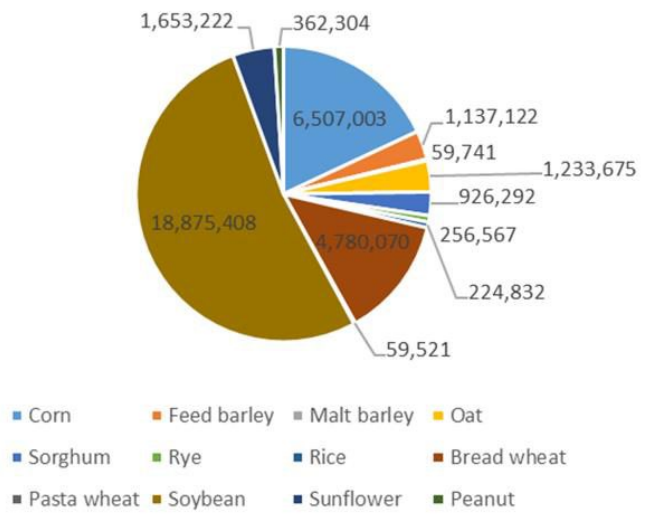

Figure 2: Average annual area (ha) for the considered crops during the period 2009-2019. Source: MAGyP, 2020

The official methodology for agricultural estimates (satellite survey of planted areas, qualified informants for production and yields, and final contrast with the volumes collected/ industrialized/exported) (Ministerio de Agroindustria; 2013) aims to obtain annual approximations that serve as the basis for adjusting multiple subjective estimates (Mirensky and Rodríguez, 2015). The methodology by which the qualified informants estimate the quantities harvested and the yields in the geographical area under their responsibility, however, is not properly documented. On the other hand, FAO recommends that countries report production figures in volumes of "clean and dry grains". The only exception is rice, which must be reported in paddy-rice quantities (FAO, 2020).

In this study the plant remains on the ground after harvesting are considered as "residues". These residues depending on the case- could be partially removed from the field (through grazing, burning, etc.) (BlancoCanqui and Lal; 2007, 2008, 2009) or almost completely extracted for cattle feed [SHp] (Menéndez; 2013; Bertoia, 2012; Romero and Aronna; 2004). When residues are produced directly at harvest time or field operation (e.g. weeding), we call them "primary residues". As usually these residues remain in the same field and are then degraded into the soil, their nutrients were not considered as "outputs" in this study.

Depending on the crop, the harvested product (be it seed, leaf, stem, etc.) is hardly pure. A quantity of biomass (remains of leaves, pods, sticks, weeds, soil aggregates, etc.) leaves the field mixed with the target product. After that, during the intermediate conditioning or transformation processes within the value-chain, variable amounts of foreign materials are separated. In the same way different losses are produced by biotic or abiotic factors, or inefficiencies inherent to the processes. We call these secondary residues [H2R] which are generated during the processing stages following harvest (Milhau and Fallot, 2013). These residues can either be traded as byproducts, discarded or even destroyed.

At the same time, all value chains generate losses of the target product. What we call primary losses are those related to inefficiencies during the harvest, but as they remain in the field, they will be incorporated into the soil and - for the purposes of this work - do not influence the export of nutrients. Then, during on-farm storage (in silo-bags or steel silos), or in mills [L2Sto] (due to pests, environmental conditions, etc.) or during transport [L2Tra] there are other losses (Bergero and Calzada, 2017; Giordano and Bianchi, 2007; Bartosik, 2018; Taher et al, 2014). 
In Argentina, the grain harvest is mainly transported by trucks. Freight rates are classified as "short" when distances are less than $80 \mathrm{~km}$ for the movement of grain from the farm to local mills. The "long" freights cover greater distances taking the grain to the final export destination, generally ports, or industry. Seventy percent of the grain produced uses both freights, while $20 \%$ receives a single long freight movement for being directly exported. The remaining $10 \%$ is being stored by growers and marketed in a different way or used on-farm (Pozzolo \& Ferrari, 2008). Due to poor truck conditions, lack of driver attention, type of truck, overload, poor road conditions, and inefficient loading and unloading processes (Pozzolo et al, 2007 and 2008) certain amounts of the product are lost and do not reach the mills, industries, or ports. We recognize here both storage and transport losses as secondary ones.

The limits of the value chains considered in the study go from the farm to the "door" of the first industrial stage $^{1}$ or the entrance to the export port. Losses and residues have not been considered in this last stage because there is not enough information for all the value-chains assessed.

The sources used were scientific articles, technical manuals, personal communications, technical diffusion bulletins to growers and journalistic references. For the nutrient content of the different grains, the same conversion tables as the bibliography were used in their updated version (García and Correndo; 2016), and experts were consulted.

In the case of some crops' losses or residues for which no references were found, the rates used were assimilated to a similar one. For example, the losses' proportions for wheat in the literature were used to calculate those of oats or barley.

\section{Results and Discussion:}

\section{Nutrient Extraction}

Figure 3 shows the total biomass exported by crop according to each of the components of the proposed nutrient balance equation (Eq 2). The [MHp] represents more than $90 \%$ of the biomass extracted in the crops of malting barley, rice, bread wheat, pasta wheat, soybeans and peanuts. In the other crops considered, the percentage varies between $6 \%$ for forage barley and rye and $89 \%$ for sunflower. Those proportions (represented in the blue bars) are those used by conventional nutrient balances.

\footnotetext{
${ }^{1}$ In the case of peanuts, the reception and conditioning stages of the raw material before entering the industrial transformation were included in the study.
} 


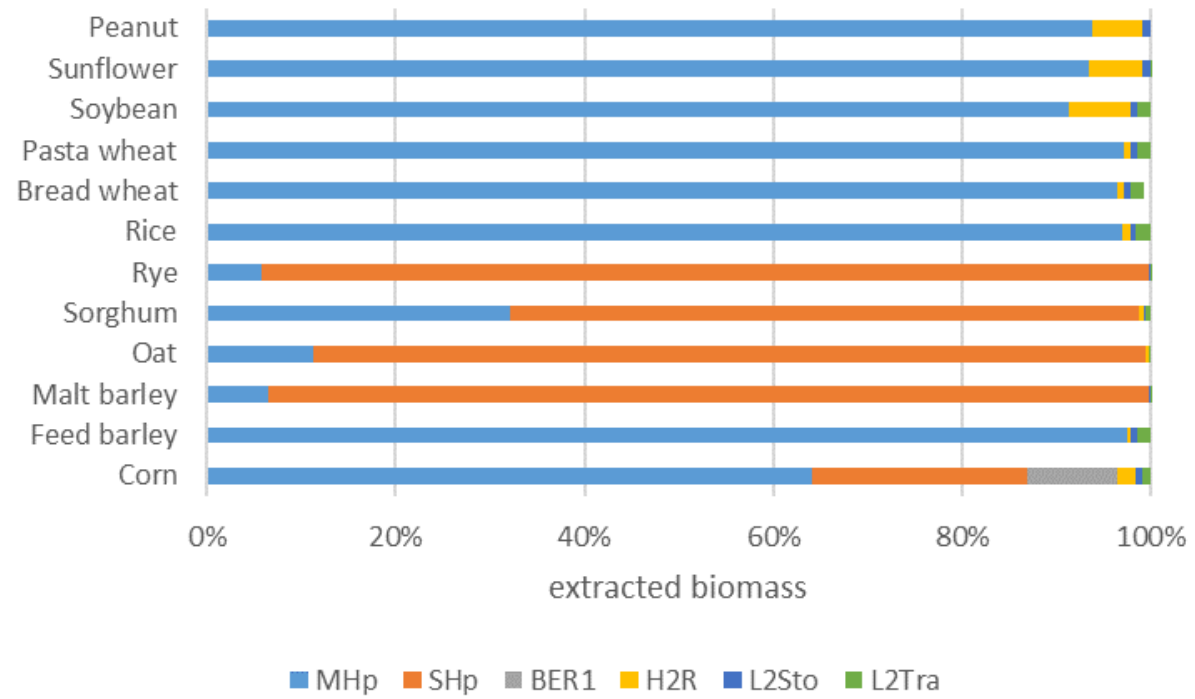

Figure 3: Average annual proportion of biomass extracted by component and crop, 2009-2019

Within the group of cereals, the proportions of extracted forage biomass are important either through mechanical harvest [SHp] (for silage for example) or direct grazing [BER1].

During the analyzed period, the concentrated beef cattle feeding systems (called feed-lots) grew steadily in Argentina, arising from the contraction of the forages and pastures' areas as a consequence of the expansion of arable land in previous decades. As the animals are kept in confined quarters rather than being allowed to range freely over grassland, these systems require the transfer of food to cattle. It is very common for corn, sorghum, wheat, barley and oat crops to be harvested as a whole plant with grain in an advanced stage of maturity and chopped for a wet forage conservation to feed the locked up cattle. Some estimates (Bertoia, 2012) indicate that between 15 and $21 \%$ of the corn area would be dedicated to forage harvesting. In the case of sorghum, the percentages could be even higher. The forage preserved in the form of silage increased its participation in cattle diet (for milk and meat) from 15 to $40 \%$ and its period of use grew from 4 to 6 months (to cover seasonal forage production potholes) to the whole year round during the decade. More than $70 \%$ of grain silage is preserved in silo-bags (Sanchez and Peiretti, 2015).

The most common method of waste recycling within feedlots, is spreading manure and bedding materials back on the cropping fields used to feed the livestock. However, because of the lack of data in this study we could not include these nutrient returns in the balances.

Even when grain itself is harvested, the residues of various crops (around 25\% of the surface in corn) (Menéndez, 2013) are directly grazed in the field [BER1]. During grazing, a part of the nutrients digested by the animals return into the soil through the manure. However, this restitution is not carried out uniformly over the entire surface, but is concentrated in certain sectors (watering places, feeders, fences, alleys, etc.) and is generally transferred outside the grazing site (enclosure yards, milking rooms, trucks, etc.). It is also common for forage reserves, even produced in the same establishment, to be supplied in paddocks other than the one of origin, implying important transfers of fertility, reaching in these sectors an increase in nutrient levels in a similar magnitude to the original condition without agricultural use. (Díaz-Zorita, 2002). As a result of these irregularities, in this work they have not been considered as a nutrients' input to the soils. In the same way, other species apart from the crop that the animals eat when grazing and that also use nutrients from the soils have not been considered. In all crops - in first instance - the proportions of biomass coming out from the soils as the considered residues and losses are much lower than those of the harvested products. However, it must 
be taken into account that even small percentages imply large volumes due to the magnitude of the planted areas.

When analyzed by nutrient content (Figure 4) it is clear that, in the case of oilseeds (soybean, sunflower, peanuts), the amount of grain harvested [MHp] is a good indicator of the nutrients exported from soil. However, in the group of cereals -with differences between species- it explains much lower percentages, leading to significantly_underestimate nutrient extraction.

When biomass for forage (stems and leaves) is harvested [SHp] the amounts of nitrogen and sulfur exported from soils are relevant (almost a third), but even more important are those of potassium, explaining more than half of the output.

If the analysis is done by individual crop (Figure 4), they could be grouped in three categories regarding the usefulness of production statistics for calculating nutrient balances:

1) those crops in which the nutrient output can be directly assimilated to the production figures $(\geq 95 \%)$ such as wheat, rice and malting barley;

2) the ones in which the volume of harvested grain partially explains nutrient exports $(\geq 50 \%-\leq 95 \%)$ like soybeans, corn, sunflower and peanuts; and

3) crops like sorghum, rye, oats or forage barley in which it would be incorrect to use the grain harvested as an indicator, since the amounts of green biomass (stems, leaves) extracted from the field are those defining the main nutrient output. 
(a)

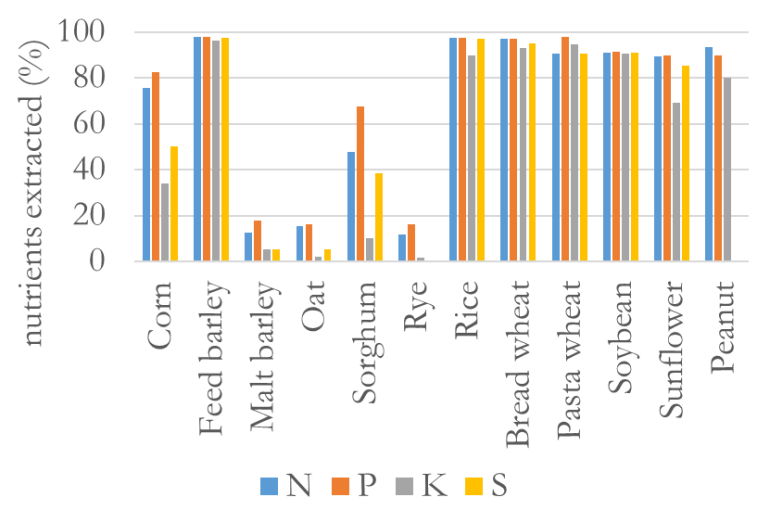

(b)

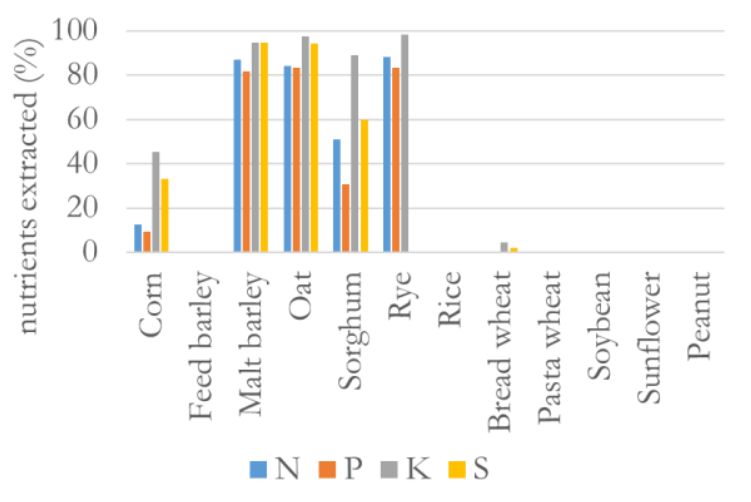

Figure 4: Average annual percentage of N, P, K and S extracted in the main harvested product [MHp] (a), and in the secondary harvested product [SHp] (b), by crop, 2009-2019

Indeed, if we compare the accumulated extraction of nutrients per hectare of the five main crops in Argentina (bread wheat, corn, soybeans, sorghum and sunflower) calculated with the conventional methodology for a national scale (Cruzate \& Casas, 2012 and 2017; Astarloa \& Pengue, 2018) and a regional one (Abbona et al, 2017), it can be seen that with our approach the levels are significantly higher than those of the literature. They are between 46 and $96 \%$ higher for N; from 25 to $78 \%$ in the case of $\mathrm{P}$ and between 176 and $272 \%$ higher for $\mathrm{K}$ (Figure 5). 


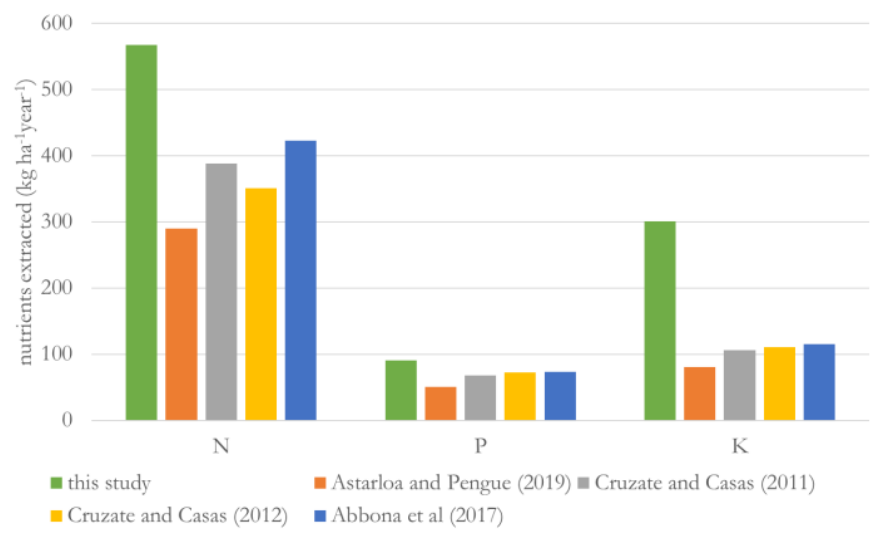

Figure 5: Compared extraction of N, P and $\mathrm{K}$ from corn + soybean + wheat + sunflower + sorghum crops (average $\mathrm{kg} \mathrm{ha}^{-1}$ year $^{-1}$ ) in different studies

\section{2 - Circularize grain residues and losses as a strategy for nutrient replenishment}

In those crops in which mainly grain is harvested, a very important amount of materials [H2R] come out jointly with the main product representing a non-considered nutrient export in conventional studies. This "dockage includes a wide variety of materials such as seeds with long rootlets, unthreshed seed heads or spikelets, chaff, dust, loose hulls, fragments of stem or rachis, soft earth pellets, broken kernels, bunt balls, stones, wild seeds, etc.

At the moment of receiving the grain, many mills carry out a "pre-cleaning" operation in order to separate certain sizes of undesirable materials that negatively affect the drying and aeration process that follows. A proportion of dust (called "volatiles") gets lost in the air during the different movements of the grains.

In corn, all these residues can represent about $3.15 \mathrm{~kg} \mathrm{~N}$ per planted hectare in an average year, representing $2.16 \%$ of the total extracted; $0.64 \mathrm{~kg} \mathrm{P} \mathrm{ha}^{-1}(2.5 \%), 0.84 \mathrm{~kg} \mathrm{~K} \mathrm{ha}^{-1}(1 \%)$ and $0.3 \mathrm{~kg} \mathrm{~S}$ ha-1 $(1.5 \%$ of the extracted). In the case of soybeans, secondary residues extract $0.6 \mathrm{~kg} \mathrm{~N} \mathrm{~kg}$ per planted hectare in an average year, or $0.35 \%$ of the total extracted; $0.25 \mathrm{~kg} \mathrm{P} \mathrm{ha}^{-1}(1.3 \%), 0.60 \mathrm{~kg} \mathrm{~K} \mathrm{ha}^{-1}(1 \%)$ and $0.04 \mathrm{~kg} \mathrm{~S}^{-1}$ ( $0.4 \%$ of the extracted).

(a)

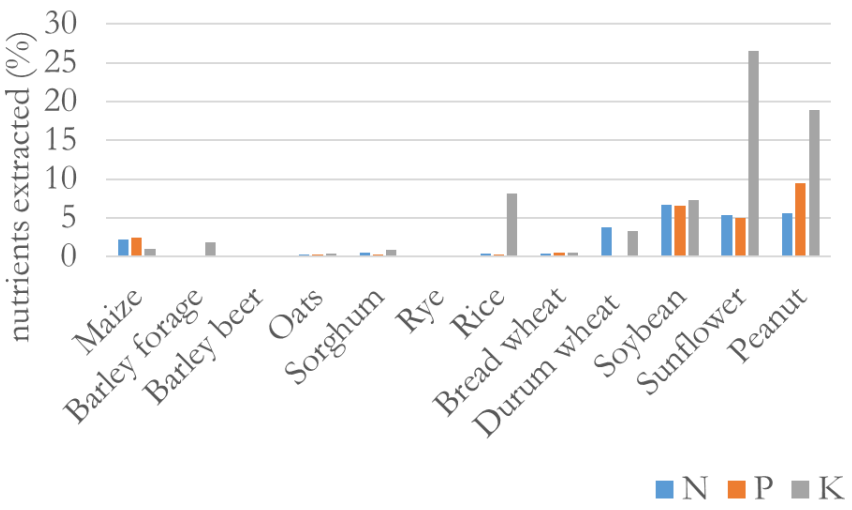

(b)

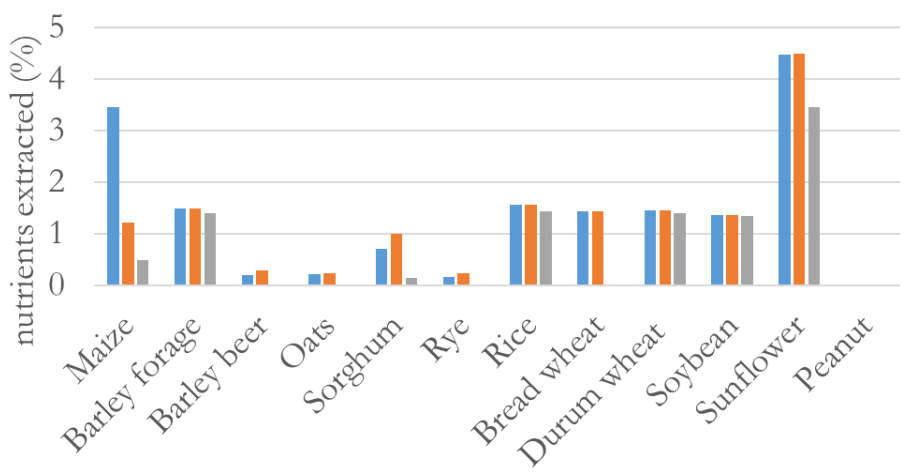

Figure 6: Average annual percentage of nitrogen $(\mathrm{N})$, phosphorus $(\mathrm{P})$ and potassium $(\mathrm{K})$ extracted in secondary harvest residues [H2R] (a) and secondary storage losses [L2Sto] (b) for the considered crops; 2009-2019 
Although the percentages are relatively low (Figure 6), the amount of $\mathrm{N}$ contained in the secondary residues of these crops would be enough to fertilize 612,000 hectares of corn (12\% of the average annual area) or 623,000 hectares of wheat $(14 \%)$ at the usual doses used by Argentinian growers (Bolsa de Cereales, 2020). The P contained in these same residues is equivalent to that applied every year to 708,000 hectares of sunflower (44\% of the average annual surface), or 944,000 hectares of sorghum (more than 100\%), for example.

Cleaning and recovering of these residues may be done on-farm, at local, sub-terminal or export elevators, or when grain is received at feed mills or processing plants. Currently these residues are mainly concentrated in the grain mills, and the volumes that could be recovered and eventually returned to the soils that originated them depend on the efficiency of the cleaning process (aspirators, screens, gravity tables and other separators) the type of dockage (small, large, dust); the dockage and foreign material levels allowed in the commercial standards, and the mill company policy. A variable percentage of extraneous material continues its way in the value-chain together with the grains and could be or not separated in other stages (e.g. ports, industries), probably further away from the fields. That would make its circularity less technically and economically feasible.

Regarding field storage, the use of silo-bags (SB) is widespread in Argentina (37\% of the total grain harvest is stored this way) (Bergero and Calzada, 2017), since it allows growers to take advantage of the seasonal prices' differences relative to harvest time. However, storage in SB presents risks. Breaks, closure problems and excess grain moisture are the main problems generating product losses [L2Sto] (Taher et al, 2014).

It is estimated that in the mills' silos there is a storage capacity of $51 \%$, while in the steel silos at the farms there is a $12 \%$ storage capacity of the total Argentine grain harvest (Bergero and Calzada, 2017).

When the silos are emptied at the end of the season, in the storage area there are grain's, insects' and even rodents' or other animal remains, etc. These residues are cleaned before the beginning of the following season (Abadía, and Bartosik, 2013). Much of this material is related to grain insect pests, which are highly variable according to storage conditions, type of insect and initial population of the same and range from $0 \%$ (without insects) to more than 1\% in case of major infestations (Bartosik, 2012).

All these components were considered as secondary storage losses [L2Sto] representing nutrients that were exported from agricultural soils. On the contrary, are not included in these calculations the weight reductions due to the respiration of the grain's mass biological components, nor the matter consumed by the fungi contained in grain if their humidity exceeds 67\% (Bartosik, 2012).

The secondary storage losses [L2Sto] of grains could be considered "potentially recyclable", assuming that the nutrients contained could eventually return to the soils that originated them. In this category fall those that geographically concentrated-are produced in silo-bags and steel silos within the same farms or in regional mills in the surroundings.

The total volume of grain lost annually during storage in Argentina exceeds the individual production of some of them: almost 1.8 million tons.

In terms of nutrients, the 77,007 tons of nitrogen in the [L2Sto] represent $8 \%$ of the total $\mathrm{N}$ applied through synthetic fertilizers $(975,843$ tons) in Argentina in 2017 for all crops. In the same way, the amount of $\mathrm{K}$ in these losses (18,790 tons) represents $43 \%$ of the 43,342 tons of total $\mathrm{K}_{2} \mathrm{O}$ applied in the country (FAOSTAT, 2020).

We have categorized as "not recyclable" the transportation secondary losses [L2Tra], which are caused by poor truck conditions, lack of attention from drivers, type of truck, overloading, poor road conditions, and deficient loading and unloading processes. These kind of losses are geographically widely dispersed and if could be avoided, the grain would simply continue to the following stages of the value-chain. Therefore, we have decided not to present a more detailed analysis here. 


\section{Limitations of this study}

A database was built collecting information on 12 crops, reviewing a wide bibliography on each of the valuechains (Table 2).

No solid references could be found on the losses and residues of all grains' species, nor the real rates of biomass extraction of each one, so for some of them extrapolations had to be made. These extrapolations may have generated inaccuracies when taken to the national and temporal scale considered.

In the same way, some references provide specific data in a specific historical moment. Given the lack of continuity in the measurements, we assumed that these values were the same throughout the decade under consideration, although knowing they must have varied over the years. Derived from this, an additional source of lack of precision in the estimates presented was the use of average values for the analyzed decade, since the parameters considered may change annually. Therefore, the weight of the planted areas and the volumes harvested are the main variability components of the values obtained for the series.

Table 2. Coefficients, values and references used for each crop component

\begin{tabular}{|c|c|c|}
\hline Coefficient & Values used & Reference \\
\hline $\begin{array}{l}\text { Nutrient contents in grains and dry matter of all } \\
\text { crops }\end{array}$ & Depend on the crop & García, F. Correndo, A.; 2016 \\
\hline [SHp] Corn area ratio for silage & $15 \%$ & Bertoia, L: 2012 \\
\hline [SHp] Rendimiento de silaje de maíz & 13 ton dry matter ha- ${ }^{-1}$ & Romero, L.; Aronna S.; 2004 \\
\hline $\begin{array}{l}\text { [BER1] Residue factor (relationship between } \\
\text { stubble and yield) of corn. FR }=(1-\mathrm{HI}) / \mathrm{HI} \\
\text { (harvest index) }\end{array}$ & $\mathrm{HI}=0,5$ & Menéndez, J. E.; 2013 \\
\hline $\begin{array}{l}\text { [BER1] Proportion of corn stubble grazed on } \\
\text { field }\end{array}$ & $\begin{array}{l}25 \% \text { (maximun recommended proportion } \\
\text { with } 1 \mathrm{cow} \mathrm{ha}^{-1} \text { ) }\end{array}$ & Blanco-Canqui y Lal; 2009 \\
\hline$[\mathrm{H} 2 \mathrm{R}]$ in corn & $3 \%$ & Bartosik, com.pers.; 2020 \\
\hline $\begin{array}{l}\text { [L2Sto] in silobags with cereals and oilseeds } \\
\text { (except groundnuts) }\end{array}$ & $2 \%$ & Taher et al; 2012 \\
\hline $\begin{array}{l}\text { [L2Sto] in metal silos and mills in cereals and } \\
\text { oilseeds (except groundnuts) }\end{array}$ & $2 \% \& 1,01 \%$ & Bartosik, com.pers.; 2020 \\
\hline [L2Tra] for corn & $\begin{array}{l}1,04 \%(70 \% \text { long }+ \text { short freight and } 20 \% \\
\text { short freight; } 10 \% \text { stays in production area) }\end{array}$ & $\begin{array}{l}\text { Pozzolo, O., Ferrari H.; Hidalgo } \\
\text { J. y Curró C.; } 2007\end{array}$ \\
\hline [L2Tra] in other cerals (except corn and rice) & $0,73 \%$ & $\begin{array}{l}\text { Pozzolo, O., Ferrari H.; Hidalgo } \\
\text { J. y Curró C.; } 2007\end{array}$ \\
\hline [L2Tra] in rice & $0,6 \%$ & Pozzolo, O., Ferrari H.; 2008 \\
\hline [RC2] in malt barley & $0,5 \%$ & $\begin{array}{l}\text { Bolsa de Comercio de Rosario; } \\
2018\end{array}$ \\
\hline $\begin{array}{l}\text { [SHp] harvested or grazed forage from forage } \\
\text { barley }\end{array}$ & 5 ton $\mathrm{ha}^{-1}$ & Tomaso, J.C.; 2009 \\
\hline$[\mathrm{H} 2 \mathrm{R}]$ in forage barley & $1 \%$ & $\begin{array}{l}\text { Bolsa de Comercio de Rosario; } \\
2018\end{array}$ \\
\hline
\end{tabular}




\begin{tabular}{|c|c|c|}
\hline [SHp] harvested or grazed forage from oats & 4 ton $\mathrm{ha}^{-1}$ & Tomaso, J.C.; 2009 \\
\hline$[\mathrm{H} 2 \mathrm{R}]$ in oats & $3 \%$ & $\begin{array}{l}\text { Bolsa de Comercio de Rosario; } \\
2018\end{array}$ \\
\hline [SHp] harvested or grazed forage from sorghum & 7 ton $\mathrm{ha}^{-1}$ & Carrasco et al.; 2011 \\
\hline$[\mathrm{H} 2 \mathrm{R}]$ in sorghum & $2 \%$ & $\begin{array}{l}\text { Bolsa de Comercio de Rosario; } \\
2018\end{array}$ \\
\hline [SHp] harvested or grazed forage from rye & 4,5 ton ha $^{-1}$ & Tomaso, J.C.; 2009 \\
\hline$[\mathrm{H} 2 \mathrm{R}]$ in rye & $0,25 \%$ & $\begin{array}{l}\text { Bolsa de Comercio de Rosario; } \\
2018\end{array}$ \\
\hline$[\mathrm{H} 2 \mathrm{R}]$ in rice & $1 \%$ & $\begin{array}{l}\text { Bolsa de Comercio de Rosario; } \\
2018\end{array}$ \\
\hline [L2Sto] in silobags and rice mills & 2 y $1 \%$ & Taher et al; 2012 \\
\hline [L2Tra] in rice & $0,6 \%$ (350 km freight) & Pozzolo, O., Ferrari H.; 2008 \\
\hline [SHp] bread wheat's forage harvested or grazed & $\begin{array}{l}2 \% \text { dual purpose area }+1,5 \text { ton dry matter } \\
\mathrm{ha}^{-1}\end{array}$ & Moreyra et al.; 2014 \\
\hline$[\mathrm{H} 2 \mathrm{R}]$ in bread wheat & Variable annual $\%$ between 0,26 and $0,55 \%$ & $\begin{array}{l}\text { Bolsa de Comercio de Rosario; } \\
2018\end{array}$ \\
\hline$[\mathrm{H} 2 \mathrm{R}]$ in pasta wheat & $0,75 \%$ & $\begin{array}{l}\text { Bolsa de Comercio de Rosario; } \\
2018\end{array}$ \\
\hline$[\mathrm{H} 2 \mathrm{R}]$ in soybean & $\begin{array}{l}7 \% \text { chaff and foreign matter separated in } \\
\text { pre-cleaning or later in the value-chain }\end{array}$ & Lasgoity, Enrique; 2018 \\
\hline$[\mathrm{L} 2 \mathrm{Tr}]$ in soybean & $\begin{array}{l}0,96 \%(80 \% \text { long }+ \text { short freight and } 20 \% \\
\text { short freight) }\end{array}$ & $\begin{array}{l}\text { Pozzolo, O., Ferrari H.; Hidalgo } \\
\text { J. y Curró C.; } 2007\end{array}$ \\
\hline$[\mathrm{H} 2 \mathrm{R}]$ in sunflower & $\begin{array}{l}6 \% \text { chaff and extraneous matter separeted } \\
\text { in pre-cleaning }+3 \% \text { extraneous matter }\end{array}$ & Bragachini, M.; Casini, C.; 2005. \\
\hline [L2Tr] in sunflower & $\begin{array}{l}0,96 \%(80 \% \text { long }+ \text { short freight and } 20 \% \\
\text { short freight) }\end{array}$ & $\begin{array}{l}\text { No reference: the same soybean } \\
\text { values were used, for similarity. }\end{array}$ \\
\hline$[\mathrm{H} 2 \mathrm{R}]$ in groundnuts & $\begin{array}{l}\text { Extraneous matters (56kg/raw seed ton). } \\
\text { Soil dust ( } 50 \mathrm{~kg} / \text { raw seed ton) }\end{array}$ & $\begin{array}{lll}\text { Bongiovanni, } & \text { Tuninetti } & \text { y } \\
\text { Garrido; } 2016 & & \end{array}$ \\
\hline [L2Tr] in groundnuts & $1 \%$. Only short freight (80 to $250 \mathrm{~km})$ & Estimation. No reference found \\
\hline
\end{tabular}

Therefore, the estimates of nutrients' exports from Argentinian soils that result from our calculations are only indicative, and should not be taken as hard data. We understand that, for this type of study, the lack of data should not limit us to propose a new approach to nutrient balances and this can be justified by explicitly described methods to convert generalized and often qualitative information into quantitative data.

With a series of estimates and general groupings, problem areas can be identified at the country level to focus future research and specify actions in each production chain. 
This approach also reveals knowledge gaps and, more importantly, indicates what kind of quantitative data we should search to obtain a greater precision. Approaches that rely on the availability of hard data as starting points lack this strong ability to indicate knowledge and data gaps.

Some over or under estimates may result from the simplification of some calculations. On a national scale, the idea is that the use of approximations to reality serves to raise awareness about the need to improve the approach to nutrient balances. At more detailed levels of scale, (for example that of farm), this approach may serve only as a wake-up call for unwanted impacts, such as the depletion of soil nutrient reserves, which plays an important role in sustainability of grains production systems and on the need for more accurate diagnoses of soil fertility.

\section{Conclusions}

The inherent fertility of Argentina's soils has made the country a major exporter of grains and nutrients to fuel the continued growth of the world's population.

Unlike more developed countries where the great concern is nutrient excess, there is enough evidence that the deficit of nutrients is a central sustainability problem for Argentinian agriculture. The problem of nutrient extraction is deepening because -among other factors- the technological changes during the last decade made the yields of the set of 12 crops (malt barley, peanuts, sunflower, soybeans, pasta wheat, corn, oats, feed barley, sorghum, rye, rice and bread wheat) gone from $3,044 \mathrm{~kg} \mathrm{ha}^{-1}$ to $3,817 \mathrm{~kg} \mathrm{ha}^{-1}(+25 \%)$. This increase had a considerable effect on the content of organic matter and the nutritional balance of the soils.

To properly address this problem, it is necessary to adapt the methodological approach avoiding the simplification of understanding the soil as a "black box" from which grains simply come out and fertilizers enter in. This study shows how in cereals this way of looking is insufficient to explain the balances, although in the case of oilseeds it could be relatively indicative of the nutritional status of the soils. In corn, sorghum, rye, oats and feed barley crops, the volume of green biomass (stems, leaves) extracted from the field are better indicators of the total nutrient output.

Therefore, if in Argentinian agricultural soils' previous references already detected an imbalance of nutrients, our results show an even greater deficit considering the current fertilization rates applied by growers (Bolsa de Cereales; 2020).

Other studies (Sainz Rosas et al., 2011 and 2019) already show a growing concern regarding a notable drop in the levels of organic matter and basic cations in Argentine soils. Among them potassium, generally considered well supplied in Pampas' soils, has shown a significant decay in its availability. This element, precisely, is an important constituent of the green biomass extracted for forage in some crops and whose importance is underestimated in conventional nutrient balances.

Having verified this worrying nutritional panorama in Argentinian soils, this study aimed to focus in grain residues and losses as a source of partial recovery of the main cations extracted by crops.

On one hand, as a general criterion it would seem in this context that trying to extract residues from these crops for other destinations or uses, would be detrimental to Argentinian soils as it would increase the already complicated nutrient deficient situation. A second consideration is that when analyzing the disposal of plant residues and/or livestock manure, the first destination to be evaluated should be agricultural soils, in the understanding that they cannot be treated as inexhaustible sources of nutrients. These residues and losses should -as far as possible- be returned into the productive system within an increasingly circular agricultural scheme. 
From the bibliographic review carried out, we deduce that the existing studies are mainly related to agroindustrial intensive value-chains, in which the disposal of their residues represents an environmental and / or social problem. As far as we know, no antecedents were found studying the losses and residues of the valuechains analyzed in this study and very few that prioritized the soil as their final destination.

This study identified two components that could contribute to a significant recycling of nutrients to the soils: the secondary harvest residues and the losses along the different stages of grain storage.

The reintroduction of these materials into the soil system could contribute not only to its nutritional improvement, but also constitute (1) a reinforcement of the physical barrier against erosion adding to that of primary crop residues in direct-planting systems; (2) a way of managing greenhouse gas emissions from soils; (3) improve soil water retention; (4) collaborate in the prevention of weed germination and (5) represent another source of carbon and organic matter. Therefore, the effective distribution of these residues and losses and their correct incorporation could greatly benefit not only soil biological activity, but also its structure, water infiltration, and its resilience against erosion and compaction.

Future research should address the technical and economic feasibility of circularizing losses and residues in grain value-chains, contributing to a greater resilience of Argentine agriculture.

\section{References}

Abadía, B., Barosik, R.; (editores); (2013); Manual de buenas prácticas en poscosecha de granos : hacia el agregado de valor en origen; Buenos Aires : Ediciones INTA, 2013

Abbona, E.; Iermanó, M.J.; Presutti, M.; Vázquez, M.; Sarandón, S.; (2017); El balance de nutrientes de las actividades agropecuarias en la provincia de Buenos Aires, Argentina: una herramienta para un manejo sustentable de los agroecosistemas a escala regional. Trabajo presentado en el VI Congreso Latinoamericano de Agroecología; Septiembre 2017.

Astarloa, D.D.; Pengue, W.A. (2018). Nutrients Metabolism of Agricultural Production in Argentina: NPK Input and Output Flows from 1961 to 2015. Ecological Economics, 147, 74-83.

Bartosik, R.; Rodríguez, J.; Cardoso, L.; 2008; Storage of corn, wheat soybean and sunflower in hermetic plastic bags. Proceedings of the International Grain Quality and Technology Congress, July 15 to 18 of 2008, Chicago, Illinois, USA

Bartosik, R.; (2012); Mermas en el Acopio de Granos; documento interno Proyecto INTA PRECOP: Eficiencia de Poscosecha; EEA INTA Balcarce.

Bergero P. y Calzada, J.; Fuerte crecimiento de la capacidad de almacenaje de granos; Boletín semanal de mercados; Bolsa de cereales de Rosario; 15/9/2017

Bergero P., Calzada, J. Sesé, A.; Estimación de la logística del transporte granelero en el país; Boletín semanal de mercados; Bolsa de cereales de Rosario; 19/5/2017

Bertoia, L: 2012; El maíz es más que un cultivo para grano; http://www.maizar.org.ar/vertext.php?id=532

Bindraban, P. S., J. J. Stoorvogel, D. M. Jansen, J. Vlaming \& J. J. R. Groot. 2000. Land quality indicators for sustainable land management: proposed method for yield gap and soil nutrient balance. Agriculture, Ecosystem \& Environment 81: 103-112. 
Blanco-Canqui H.y Lal R. 2007. Soil and crop response to harvesting corn residues for biofuel production. Journal/Geoderma 141.355-362.

Blanco-Canqui H.y Lal R. 2008. Corn stover removal impacts on micro-scale soil physical properties. Journal/Geoderma. 145. 335-346.

Blanco-Canqui H.y Lal R. 2009. Corn stover removal for expanded uses reduces soil fertility and structural stability. Journal/Soil Sci. Soc. Am. J. 73. 418-426

Bolsa de Cereales; 2018; Balance de nutrientes Campaña 2016/17; Informe ReTAA N5; Departamento de Investigación http://www.bolsadecereales.com/imagenes/retaa/2017/ReTAA MesN5 Nutrientes 2802 18.pdf

Bolsa de Cereales; 2019; Balance de nutrientes Campaña 2017/18; Informe ReTAA N¹7; Departamento de Investigación y Prospectiva. http://www.bolsadecereales.com/imagenes/retaa/2019-02/165informen17balancedenutrientes1718.pdf

Bolsa de Cereales; 2020; Balance de nutrientes Campaña 2018/19; Informe ReTAA N²9; Departamento de Investigación y Prospectiva. http://www.bolsadecereales.com/imagenes/retaa/2020-02/200informen29 balance de nutrientes 18 19.pdf

Ciampitti, I.A., García, F.O., 2011. Requerimientos nutricionales, absorción y extracción de macronutrientes y nutrientes secundarios. II. Hortalizas, Frutales y Forrajeras. Arch. Agron. 12, 1-4.

Cruzate, G.A., y R. Casas. 2009. Extracción de Nutrientes en la Agricultura Argentina. Informaciones Agronómicas del Cono Sur, IPNI; 44:21-26.

Cruzate, G.A., Casas, R., 2012. Extracción y balance de nutrientes en los suelos agrícolas de la Argentina. Informaciones Agronómicas del Cono Sur, IPNI; 6, 7-14.

Cruzate, G.A., y R.R. Casas. 2017. Balance de nutrientes en los suelos agrícolas de la Argentina en la campaña 2015/16; Informaciones Agronómicas de Hispanoamérica 28:14-23.

Díaz-Zorita, M.; 2002; Ciclado de nutrientes en sistemas pastoriles; Sitio Argentino de Producción Animal; http://www.produccion-animal.com.ar/suelos_ganaderos/52-ciclado_nutrientes.pdf

Di Ciocco, C., Álvarez, R., Andrada, Y., Momo, F.; (2004); Nitrogen balance in a soybean crop; (2004) Ciencia del Suelo, 22 (1), pp. 48-51

D'Odorico, P.; Bhattachan, A.; Davis, K.F.; Ravi, S.; Runyan, C.W.; 2013; Global desertification: Drivers and feedbacks; Advances in Water Resources; Volume 51, January 2013, Pages 326-344

FAO; 2001; Assessment of soil nutrient balance: Approaches and methodologies; Fertilizer and Plant Nutrition Bulletin $\mathrm{n}^{\circ} 14$

FAOSTAT; 2020; Crops Statistics - Concepts, Definitions and Classifications; http://www.fao.org/economic/the-statistics-division-ess/methodology/methodology-systems/cropsstatistics-concepts-definitions-and-classifications/en/

Flores, C.C.; Sarandón, S.J.; ¿Racionalidad económica versus sustentabilidad ecológica? El ejemplo del costo oculto de la pérdida de fertilidad del suelo, durante el proceso de Agriculturización en la Región Pampeana Argentina. Revista de la Facultad de Agronomía 105 (1): 53-67, 2003 
García, F.O., Correndo, A.A., (2016); Cálculo de requerimientos nutricionales. Cereales, Oleaginosas, Industriales, Forrajeras y Hortalizas. IPNI. http://lacs.ipni.net/article/ LACS-1024, Accessed date: July 2020

García F. O.; González San Juan M.F.; 2011; La nutrición de suelos y cultivos y el balance de nutrientes: ¿cómo estamos?; Revista IPNI Cono Sur Argentina. Fertilizar Asociación Civil

Giordano, J.M.; Bianchi, E.; 2007; Caracterización de las condiciones del almacenamiento en el área centro de la Provincia de Santa Fé; Información Técnica Cultivos de Verano. Campaña 2007; Publicación Miscelánea No 108; INTA - Estación Experimental Agropecuaria Rafaela. http://rafaela.inta.gov.ar/info/miscelaneas/108/misc 108 135.pdf

Instituto Nacional de Estadística y Censos - I.N.D.E.C.; Censo Nacional Agropecuario 2018 : resultados preliminares : agricultura : enero de 2020. - $1^{\text {a }}$ ed. - Ciudad Autónoma de Buenos Aires : Instituto Nacional de Estadística y Censos - INDEC, 2020. https://cna2018.indec.gob.ar/el-censo-en-cifras.html

Lavado R. S. y Taboada M.A.; 2009; The Argentinean Pampas: A key region with a negative nutrient balance and soil degradation needs better nutrient management and conservation programs to sustain its future viability as a world agroresource; Soil and Water Conservation Society; doi:10.2489/jswc.64.5.150A

Menéndez, Julio E.; 2013; Cuantificación y uso de Biomasa de residuos de cultivos en Argentina para bioenergía / Julio E. Menéndez y Jorge Antonio Hilbert; Jorge Antonio Hilbert, editor. - Buenos Aires; INTA, 2013.

Milhau A.; Fallot, A.; (2013); Assessing the potentials of agricultural residues for energy: What the CDM experience of India tells us about their availability; Energy Policy, Volume 58, 2013, Pages 391-402, ISSN 03014215, https://doi.org/10.1016/j.enpol.2013.03.041.

Ministerio de Agroindustria; (2013); Método de Segmentos Aleatorios: Metodología para la estimación de la superficie sembrada con cultivos extensivos; Versión https://www.magyp.gob.ar/sitio/areas/estimaciones/estimaciones/metodologia/_archivos//000000_Metod o $\% 20$ de $\% 20$ segmentos $\% 20$ aleatorios $\% 20($ Version $\% 205)$.pdf

Ministerio de Agroindustria (2018); Argentina: Estudio Pérdidas y desperdicios de alimentos vinculado al Objetivo Desarrollo Sostenible para garantizar producción y consumo responsable (ODS 12); Resumen del informe final; Octubre 2018.

http://www.alimentosargentinos.gob.ar/HomeAlimentos/ValoremoslosAlimentos/documentos/Resumen Propuesta Cuantificacion PDA ODS.pdf

Mirensky, J.; Rodriguez N.V.; (2015); Metodología estadística para la estimación de las superficies sembradas con cultivos extensivos - método de segmentos aleatorios; Revista Argentina de Estadística Aplicada; Año 2, no2. http://untref.edu.ar/raesta/n2 art6.php

Pozzolo, O., Ferrari H.; Hidalgo J. y Curró C.; 2007; Pérdidas de Grano de Maíz en Transporte por Carretera; EEA INTA C. del Uruguay; Programa Nacional Agroindustria y Valor Agregado - Proyecto Integrador Procesos Tecnológicos para Agregar Valor en Origen en forma Sustentable. http://www.cosechaypostcosecha.org/data/articulos/cosecha/PerdidasGranoMaizTransporteCarretera.asp

Pozzolo, O., Ferrari H.; 2008; Pérdidas de Grano de Arroz en Transporte por Carretera; EEA INTA C. del Uruguay; Programa Nacional Agroindustria y Valor Agregado - Proyecto Integrador Procesos Tecnológicos para Agregar Valor en Origen en forma Sustentable. http://www.cosechaypostcosecha.org/data/articulos/postcosecha/PerdidasGranoArrozTransporteCarretera. asp 
Romero, L.; Aronna S.; 2004; Siembra de maíz para silaje; Proyecto Regional de Lechería; Campaña de Forrajes Conservados 2003-2004; EEA INTA Rafaela. http://rafaela.inta.gov.ar/info/documentos/cfc/doc2.pdf

Roy, R. N., Misra, R. V, Lesschen, J. P., and Smaling, E. M. A.; 2003; Assessment of Soil Nutrient Balance. Approaches and Methodologies, FAO Fertilizer and Plant Nutrition Bulletin, 14, FAO, Rome, 2003.

Sainz Rozas, H., Echeverría, H., Angelini H.; 2011; Niveles de carbono orgánico y ph en suelos agrícolas de las regiones pampeana y extrapampeana argentina; Ciencia del suelo, ISSN 0326-3169, Vol. 29, Nº. 1, 2011, págs. 29-37.

Sainz Rozas H., Eyherabide M., Larrea G., Martínez Cuesta N., Angelini H., Reussi Calvo N., Wyngaard N.; 2019; Relevamiento y determinación de propiedades químicas en suelos de aptitud agrícola de la región pampeana; Presentación en el $14^{\circ}$ Simposio Fertilidad, Mayo 2019. https://inta.gob.ar/sites/default/files/relevamiento_y_determinacion_de_propiedades_quimicas_en_suelos_ de_aptitud_agricola_de_la_region_pampeana_.pdf

Salvagiotti, F; DJ Collino; A Perticari; C Piccinetti; G Ovando; S Urquiaga \& RW Racca. 2015. El aporte de la fijación biológica de nitrógeno en el cultivo de soja en Argentina. Informaciones Agronómicas de Hispanoamérica 20- Diciembre - Versión Cono Sur.

Sanchez, F.R.; Peiretti, J.; 2015; Tecnología de picado para ensilado de cultivo de maíz; Actualización técnica no85; TecnoForrajes; EEA INTA Manfredi. https://inta.gob.ar/documentos/tecnologia-de-picado-paraensilado-de-cultivo-de-maiz

Scherer L., Svenning J.-C., Huang J., Seymour C.L., Sandel B., Mueller N., Kummu M., Bekunda, M.i, Bruelheide, H.j,k, Hochman, Z.l, Siebert, S.m, Rueda, O.a, van Bodegom P.M.; 2020; Global priorities of environmental issues to combat food insecurity and biodiversity loss; (2020) Science of the Total Environment, 730 , art. no. 139096

Smith, P, Calvin, K, Nkem, J, et al.; Which practices co-deliver food security, climate change mitigation and adaptation, and combat land degradation and desertification? Glob Change Biol. 2020; 26: 1532- 1575. https://doi.org/10.1111/gcb.14878

Sterk, G.; Stoorvogel, J.J.; 2020; Desertification-Scientific versus political realities; Land; Volume 9, Issue 5, 1 May 2020, Article number 156

Taher H., Urcola H., Cardoso L., Bartosik R.; 2014; Percepción de los productores sobre Beneficios y Problemáticas en el Almacenamiento en Silo bolsa; 1er Congreso Internacional de Almacenamiento de Granos en Silo Bolsa, 2014. https://inta.gob.ar/sites/default/files/script-tmp-inta-t2n3 taher_et_al.pdf

Tully, K.L.; McAskill, C.; 2020; Promoting soil health in organically managed systems: a review(Review); Organic Agriculture Volume 10, Issue 3, 1 September 2020, Pages 339-358

Viglizzo, E.F., Lértora, F.A., Pordomingo, A.J., Bernardos, J.N., Roberto, Z.E., Del Valle, H., 2001. Ecological lessons and applications from one century of low external-input farming in the pampas of Argentina. Agric. Ecosyst. Environ. 81, 65- 81.

Viglizzo, E.F.; Carreño, L.V.; Pereyra, H.; Ricard, F.; Clatt J.; Pincén. D.; Dinámica de la frontera agropecuaria y cambio tecnológico. En: Expansión de la Frontera Agropecuaria en Argentina y su Impacto EcológicoAmbiental. Ediciones INTA. Viglizzo, E.F. \& E.G. Jobbágy Editores. Capítulo 1:9-16, 2010. 